\title{
自由界面を有する矩形容器内自然対流の伝熱現象と赤外線計測*
}

\author{
稲 垣 照 美*1，金 児 敏 信*2 \\ 羽 鳥 雅 一*2, 椎 名 保 顕*3
}

\section{Heat Transfer Phenomenon of Natural Convection in an Open Vessel and Its Infrared Sensing}

\author{
Terumi INAGAKI*4, Toshinobu KANEKO, \\ Masakazu HATORI and Yasuaki SHIINA \\ ${ }^{* 4}$ Mechanical Engineering, Ibaraki University, \\ 4-12-1 Nakanarusawa, Hitachi-shi, Ibaraki, 316-8511 Japan
}

\begin{abstract}
As infrared thermography has a convenient feature that we can diagnose two-dimensional temperature fields nondestructively and simultaneously at every picture element, it has widely been applied to various engineering applications. Therefore, in this paper, the free surface temperature field was visualized and measured by sensing infrared energy emitted from the liquid-gas interface directly as electromagnetic waves. The heat transfer phenomena were also discussed by analyzing the temperature data statistically. Another aim is to confirm the applicability of infrared thermography to quantitative heat transfer measurement for a liquid-gas interface.
\end{abstract}

Key Words: Infrared Thermography, Thermal Visualization, Liquid-gas Interface, Heat Transfer, Natural Convection

\section{1. 粕 言}

赤外線サーモグラフィーは, 対象物から発せられる 熱エネルギーを感知し，その表面温度を非破壊リモー トセンシングに評価する手段であるとともに, 複雑な 形状を有する二次元温度場をリアルタイムに,かつ画 素毎に診断・評価することが可能な手段である.その ため, この手法は, 工学, 理学, 医学あるいは産業界を始 めとする様々な分野で広く利用されている.一方, 伝熱 学の分野においては,これまで主に加熱固体壁面の温 度計測あるいは伝熱計測 ${ }^{(1)}$ に利用されてきたが, 赤外 線計測の気液界面現象への定量的な適応性や有効性に ついては十分な知見が得られているとは言い難い．

このことから, 本研究では, 気液界面伝熱現象の代表 例として,片面に自由界面を有する有限矩形容器内の ベナールセル対流を取り上げ,その可視化や温度・伝熱 計測に赤外線サーモグラフィーを応用することにした. すなわち, 自由界面に接するべナールセル対流に及ほ 寸容器アスペクト比, 粘性係数, 流体層深さ及び加熱量 の影響について実験と数值シミュレーションの両面か ら併せて考察を進め, 赤外線サーモグラフィーによる 気液界面伝熱計測への適応性や有効性の確立を図るこ とにした.さらに, 赤外線サーモグラフィーによる気液

* 原稿受付 2003 年 11 月 20 日.

*! 正員, 茨城大学工学部（316-8511 日立市中成沢町 4-12 1).

*2 茨城大学大学院理工学研究科.

*3 正員, 日本原子力研究所大洗研究所 (-311-1934 東茨城郡 大洗町成田町新堀 3607).

E-mail : inagaki@mech.ibaraki.ac.jp
界面の定量的な温度計測を実施し, 本手法の定量化を 進めた. 気液界面の伝熱現象を解明する上では, 赤外線 サーモグラフィーのような非接触な計測が望ましいと 言える.なお, 上下面とも固体壁面で拘束されたべナー ルセル対流に関しては, 従来から多くの研究が行われ ている (例えば文献 (2)) が, 自由界面を有する場合 ${ }^{(3),(4)}$ はあまり多くの研究がなされていない.

\section{2. 実験装置及び計測方法}

$2 \cdot 1$ 赤外線サ一モグラフィーの特性ここでは, 赤外線サーモグラフィーの基本的な特性や具体的な データ処理法について述べることにする. 本研究で利 用している赤外線サーモグラフィー装置は, NEC 三栄 製 TH3102MR 型サーモトレーサ (スターリング冷却方 式, Hd-Cd-Te センサ, 検出波長域 $8 \sim 13[\mu \mathrm{m}]$, 温度測定 範囲 $-50 \sim+2000\left[{ }^{\circ} \mathrm{C}\right]$, 最小検知温度分解能 $\left.0.1\left[{ }^{\circ} \mathrm{C}\right]\right)$ である. ある 1 つの熱画像は, 水平方向に 255 画素, そ れと直交する垂直方向に239 画素から構成されている。

一般に, 1 つの熱画像当たりの水平及び垂直走査範囲 は, 赤外線サーモグラフィー装置の検出部之計測対象 との距離によって異なる.例えば, $500[\mathrm{~mm}]$ において 水平走查範囲:308 [mm], 垂直走査範囲: $292[\mathrm{~mm}]$ 及び $1000[\mathrm{~mm}]$ において水平走査範囲: $576[\mathrm{~mm}]$, 垂直走査 範囲:546 [mm] である.一方, 熱画像生成時間は, 1 つの 熱画像が 239 本の水平走查ラインで構成されているの 
で, ある 1 つの水平ラインを走査して次の走査までに 3.125 [ms] を要する.この走查時間 $3.125[\mathrm{~ms}]$ の中に は, CRT 表示時間 1.25 [ms] が含まれている. 従って, 1 画像生成時間は, $3.125[\mathrm{~ms}] \times 239$ 本 $\fallingdotseq 0.75[\mathrm{~s}]$ となる. その他, 赤外線サーモグラフィーによる定量計測では, 最小検知寸法 ${ }^{(5)}$, ノイズ相当温度差 ${ }^{(6)}$ 及び熱画像ひず み(7) などが及ぼす影響を考慮に入れる必要がある.な お,ラインスキャンモードを利用すれば,任意水平走査 線上の温度や任意点の温度を最高 $3.125[\mathrm{~ms}]$ の速度で 採取することが可能になる.

以上は, 赤外線サーモグラフィー装置から直接得られ た界面温度 (見掛け温度 $T_{r}$ ) に関する取り扱いである。 熱伝達率を評価する上で重要な真の界面温度 $T_{s}$ は, シ リコンオイルを充填した恒温水槽による検定実験から 得られた検定直線に基づいて見掛け温度から求めてい る.すなわち, 検定用の恒温面を計測して対比させてい る. なお, 矩形容器内に充填したシリコンオイルを容器 底面から加熱しながら界面を赤外線サーモグラフィー 装置で撮影するのと同時に, 界面極近傍 (界面から 300 $[\mu \mathrm{m}]$ 液側に溶接部全体を浸潤) の温度を予め検定した 直径 $300[\mu \mathrm{m}]$ の C-A 熱電対を用いて計測し，参照し た.ここでは，校正した温度を $T_{s}$ として真の温度と見な している. 気液界面では, 赤外線の透過率が小さく, か つ表面の放射率 $(0.98 \pm 0.01)$ が大きいため,例え放射 率がこの範囲で変化しても十分な計測精度 (1 [\%] 以 下)が得られる.

\section{2 実験装置と計測方法図 1 と図 2 は, 実験} 装置の概略を示したものである. 伝熱面は, 上から銅 板 (厚さ $1[\mathrm{~mm}]$ ), そして熱源であるステンレス箔 (幅 $10[\mathrm{~mm}]$ の短冊上に加工, 厚さ $30[\mu \mathrm{m}])$ の順に張り 合わせ, 周囲を十分に断熱した厚さ $10[\mathrm{~mm}]$ の水平 なアクリル矩形容器 (濡れ縁面積 $A_{0}=w_{1} \times w_{2}\left[\mathrm{~mm}^{2}\right]$ ) の底面に固定した. 実験では, $w_{1} \times w_{2}=100[\mathrm{~mm}] \times 100$ $[\mathrm{mm}]($ Type A), $100[\mathrm{~mm}] \times 200[\mathrm{~mm}]($ Type B) 及び 100 $[\mathrm{mm}] \times 300[\mathrm{~mm}]($ Type C) の容器アスペクト比が異な る 3 種類のアクリル矩形容器を用いている. 但し, 矩 形容器の高さは $20[\mathrm{~mm}]$ で同一である. 伝熱面は, 銅 板を設置していることから, 温度一定条件下で加熱で きる. 伝熱面 (加熱面) 温度の計測は, 予め検定した直 径 $100[\mu \mathrm{m}]$ の C-A 熱電対を銅板の裏面に 5ヶ所ス ポット溶接して行った. また, 矩形容器底部裹面からの 漏洩熱量を計測するため, ゼネレクス社製 BF-04 型の 熱流束センサ (サイズ:25[mm]×25[mm], 標準感度: 10 $\left[\mathrm{mV} /\left(\mathrm{W} / \mathrm{cm}^{2}\right)\right]$, 最小感知熱量: $0.008\left[\mathrm{~W} / \mathrm{cm}^{2}\right]$, 使用可能 温度範囲: $\left.-50\left[{ }^{\circ} \mathrm{C}\right] \sim+180\left[{ }^{\circ} \mathrm{C}\right]\right)$ を底部に直接貼り付 けて正味熱流束 $q$ の補正を行った。さらに,多重反射

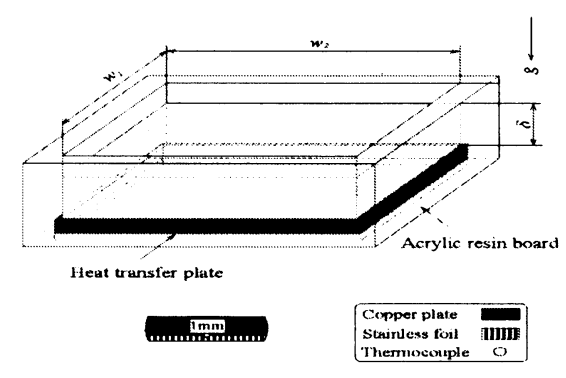

Fig. 1 Experimental Apparatus

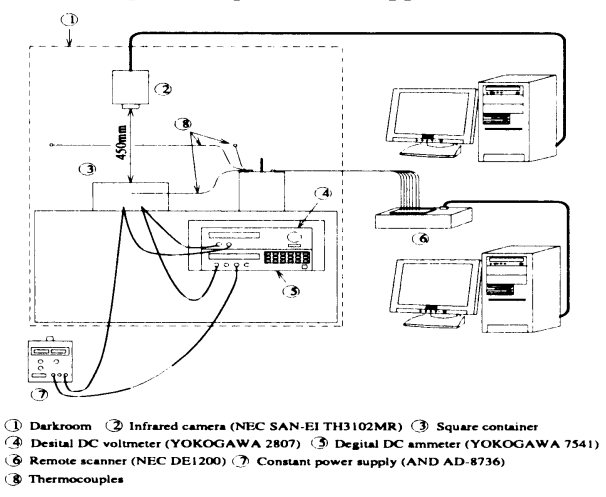

Fig. 2 Measuring System

の影響を極力避けるため, 一定温度に空調された暗室 内に赤外線サーモグラフィー装置の検出部と実験装置 を同時に設置し, 気液界面温度計測を検出部から 0.45 $[\mathrm{m}]$ の距離で一連の計測を実施した. 実験では, ベナー ルセル対流に及ぼす粘性の影響と流体層深さ $\delta$ の影響 を評価するため, 作動流体として椂々な粘度を有する シリコンオイルを矩形容器内の様々な高さまで充填し た.すなわち, 動粘度 $v$ が $50,100,300,500$ [cst] の 4 種 類を用意し, 流体層深さ $\delta$ を $5,10,15[\mathrm{~mm}]$ と変化さ せた. 加熱は, 短冊状にしたステンレス箔を直流定電圧 電源 (CUSTOM CPS-1850) でジュール加熱することで 達成した. そのため, 配線間には電流計 (YOKOGAWA 7541) と電圧計 (YOKOGAWA 2807) を捚入して電流及 び電圧を計測している. 周囲流体温度としての暗室内 温度は, 直径 $300[\mu \mathrm{m}]$ の C-A 熱電対を検出部と装置 の中間付近に 2 所取り付けて計測した. 各種の温度 データは, 零点補償した後, リモートスキャナー (NEC SAN-EI 製 DE1200) を通してコンピューターに採取さ れ, 各種の無次元数を計算した.これら無次元数に供す べき物性值は, 液相内の場合, 加熱面温度 $T_{w}$ と周囲流 体温度 $T_{g}$ の平均温度 (膜温度)に基づいて決定してい る. 赤外線サーモグラフィー装置から得られた熱画像 データは, データキャプチャプログラム (NEC SAN-EI TH31-402)により各画素毎の温度に加工した.なお,一 連の計測は, 各熱電対や熱流束センサ及び赤外線サー 
モグラフィーで観測している加熱面・表面温度や熱流 束が定常状態に至った後, 実施している. データキャプ チャの際は, 自動環境補正を行い, レンジ $(-504 \sim+200$ $\left.\left[{ }^{\circ} \mathrm{C}\right]\right)$, オートフォーカスを設定して計測を行った.

一方, 本研究では, 気液界面において, 如何なる流動 現象が生じているのかを確認するため, アルミパウダー を併用した流動パターンの可視化も同時に行った.こ れは, 赤外線計測によっても熱流動現象の様子を充分 に観察できることを実証するためでもある.なお, 撮影 は, 流れが定常となった段階からデジタルビデオカメ ラで行い, 気液界面とカメラの距離は $0.45[\mathrm{~m}]$ とした.

\section{3. 実験結果及び考察}

3.1 気液界面温度場の可視化図 $4 \sim$ 図 10 は, 気液界面上に発生する自然対流の伝熱・流動現象を赤 外線サーモグラフィーにより可視化した結果の一例で ある.これらの温度場可視化画像では, 色パターンを例 示した図 3 に示すように高温領域が赤系色, 低温領域 が青系色で表示されている. 図中のレイリ数 $R a_{l}$ は, 流 体層側のレイリ数 $\left[R a_{l}=\operatorname{Pr}_{l} g \beta_{l}\left(T_{w}-T_{g}\right) \delta^{3} / v_{l}^{2}\right]$ であ り, 重力加速度 $g$, 体積膨張率 $\beta_{l}$, プラントル数 $P r_{l}$ を 用いて算出することができる. 下付添字 $l$ は, 液層を意 味する. また, 表 1 は, 各実験装㯰毎のべナール対流発 生の条件である臨界レイリ数 $R a_{c}{ }^{\left({ }^{(8)}\right.}$ を示したものであ る.レイリ数がこれらの值を越えた付近から, 流体層内 は熱伝導支配下から対流支配に移行し, ベナールセル が発生し始めることになる.下付添字 $c$ は, 臨界值を意 味する.

Table 1 Critical Rayleigh number

\begin{tabular}{|c|c|c|}
\hline Apparatus & $\delta[\mathrm{mm}]$ & $R a_{c}$ \\
\hline \multirow{3}{*}{ Type A } & 5 & 1107 \\
\cline { 2 - 3 }$\left(A_{0}=100 \times 100\right)$ & 10 & 1124 \\
\cline { 2 - 3 } Type B & 15 & 1150 \\
\cline { 2 - 3 } & 5 & 1104 \\
\cline { 2 - 3 }$\left(A_{0}=100 \times 200\right)$ & 10 & 1114 \\
\hline Type C & 5 & 1129 \\
\cline { 2 - 3 }$\left(A_{0}=100 \times 300\right)$ & 10 & 1111 \\
\cline { 2 - 3 } & 15 & 1123 \\
\hline
\end{tabular}

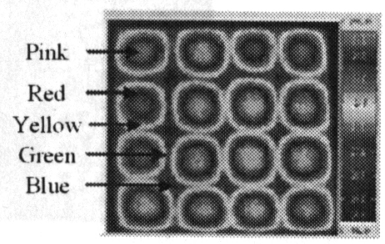

Fig. 3 Concept Model of Visualized Thermal Pattern

図 $4 \sim 6$ の (a) (c) は, 実験装置 Type A,Type B,Type $\mathrm{C}$ において, $v=100$ [cst] $\delta=5[\mathrm{~mm}]$ と固定し, 加熱量 $q$
を増加させて可視化した気液界面温度場の様子である。 いずれの装置においても, 表 1 に示す $R a_{c}$ 以下の時, つ まり加熱量が非常に小さい時, 気液界面は均一な温度 分布となっていることが図 $4 \sim 6$ の (a) から分かる. ま た, 流体層涾さが小さい場合, 熱画像の縮尺の関係で分 かりにくいが, どの装置, どの加熱量においてもセル寸 法はほぼ同一であり, 乱流遷移しにくい.

図 $7 \sim 9$ の (a)〜(d) は, 実験装置 Type A,Type B,Type $\mathrm{C}$ において, $v=100$ [cst], $\delta=10$ [mm] と固定し, 加熱量 を増加させて可視化した気液界面温度場の様子である. 加熱量が増加することでベナールセル対流が発生し, セルが発生した後, 最終的に崩れていく様子が図 7〜9 の (a)〜 (d) から分かる.この際, セル寸法や形状, 発生位 㯰が時々刻々と変化し始める.すなわち, 図 7 9 の (d) に示すように, セルの出現位置と形は不規則に変化し, かつ非定在的になる.一方, $\delta=5[\mathrm{~mm}]$ の場合と同様に, 加熱量が非常に小さいと気液界面は均一な温度分布に なる. 加熱量が増加すると, セル同士が合体した後, 図 7〜図 9 の (c) に見られるようにセル同士が合体・成長 して発生数が減少し, 最終的に崩壊する.

図 10 の (a) (d) は, 実験装置 Type A,Type B,Type C において, $v=100$ [cst], $\delta=15[\mathrm{~mm}]$ と固定し, 可視化し た気液界面温度場の様子である.Type A では, 前述の実 験結果と同様に, 加熱量が増加するとセルが発生し, 最 終的に崩壊する様子が (a), (b) から分かる.また, 流体 層樑さが大きくなると,いずれの容器アスペクト比に 対しても, セル寸法が増大していることが分かる。

図 11 は, 実験装置 Type A において, $\delta=10[\mathrm{~mm}], q$ $\fallingdotseq 170\left[\mathrm{~W} / \mathrm{m}^{2}\right]$ 付近に固定し, 動粘度を増加させて可視 化した気液界面温度場の様子である. $v=50$ [cst] にお けるセル寸法については, 他の粘性のものより大きく なっているが, 他の粘性については顕著な違いは見ら れない.

以上の結果から, 赤外線計測は, 気液界面の温度場を 可視化する上で有効な手段であると言える.

3.2 気液界面の温度場と流れ場の可視化図 12 の (a) と (b) は実験装置 Type A における $v=300$ [cst], $\delta=5[\mathrm{~mm}]$ に対して, 図 13 の (a) と (b) は実験装置 Type A における $v=300$ [cst] $\delta=10$ [mm] に対する気液界面 温度場と流れ場の同時可視化画像を示したものである. 温度と速度場の動画像を解析すると, 加熱面で暖めら れた流体が赤や桃を呈した部分の気液界面へ向かって 上昇し, 界面で冷やされた後, 青や緑を呈した部分から 加熱面へ向かって下降していた. その結果, 気液界面で は幾何境界の影響を受けつつ, 様々な色や形をした模様 が出現する.このことから, 赤外線計測で明らかになっ 


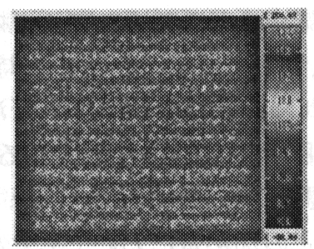

(a) $R a_{l}=1.73 \times 10^{2}$ $q=18.8\left[\mathrm{~W} / \mathrm{m}^{2}\right]$

Fig. 4

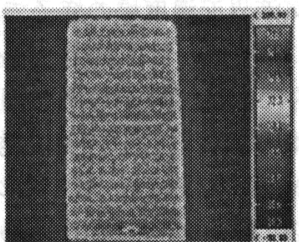

(a) $R a_{l}=2.73 \times 10^{2}$ $q=19.8\left[\mathrm{~W} / \mathrm{m}^{2}\right]$

Fig. 5

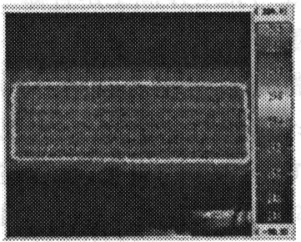

(a) $R a_{l}=3.75 \times 10^{2}$ $q=22.0\left[\mathrm{~W} / \mathrm{m}^{2}\right]$

Fig. 6

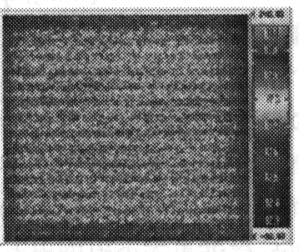

(a) $R a_{l}=4.39 \times 10^{2}$ $q=20.4\left[\mathrm{~W} / \mathrm{m}^{2}\right]$

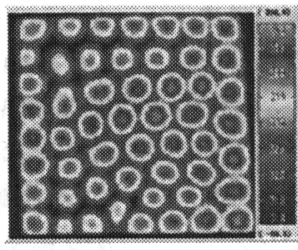

$$
\begin{aligned}
& \text { (b) } R a_{l}=3.87 \times 10^{3} \\
& q=462.3\left[\mathrm{~W} / \mathrm{m}^{2}\right]
\end{aligned}
$$

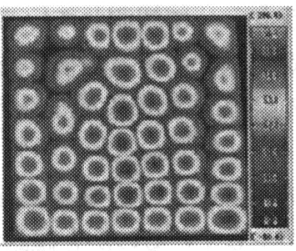

(c) $R a_{1}=8.37 \times 10^{3}$ $q=824.4\left[\mathrm{~W} / \mathrm{m}^{2}\right]$
Visualized Thermal Patterns (Type A, $v=100$ [cst], $\delta=5[\mathrm{~mm}]$ )

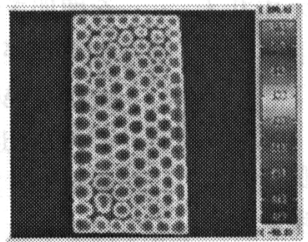

$$
\begin{aligned}
& \text { (b) } R a_{l}=5.24 \times 10^{3} \\
& q=414.4\left[\mathrm{~W} / \mathrm{m}^{2}\right]
\end{aligned}
$$

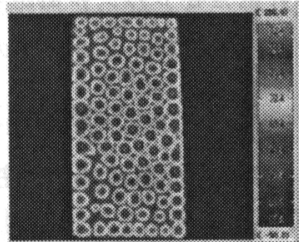

(c) $R a_{l}=1.04 \times 10^{4}$ $q=714.2\left[\mathrm{~W} / \mathrm{m}^{2}\right]$
Visualized Thermal Patterns (Type B, $v=100$ [cst], $\delta=5[\mathrm{~mm}]$ )

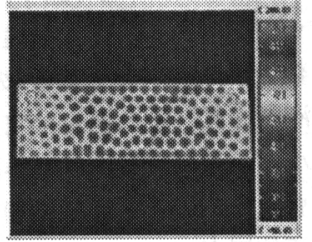

(b) $R a_{l}=3.41 \times 10^{3}$

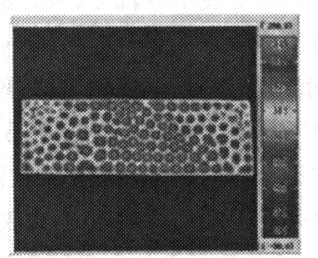

(c) $R a_{l}=6.26 \times 10^{3}$

$q=413.6\left[\mathrm{~W} / \mathrm{m}^{2}\right]$
Visualized Thermal Patterns (Type C, $v=100[\mathrm{cst}], \delta=5[\mathrm{~mm}]$ )

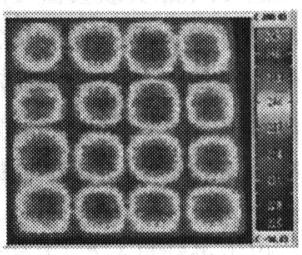

(b) $R a_{l}=2.39 \times 10^{3}$ $q=117.5\left[\mathrm{~W} / \mathrm{m}^{2}\right]$

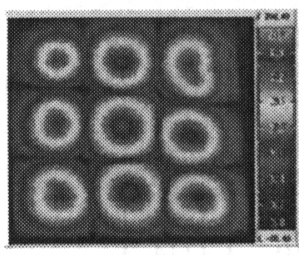

(c) $R a_{l}=8.58 \times 10^{3}$ $q=454.7\left[\mathrm{~W} / \mathrm{m}^{2}\right]$

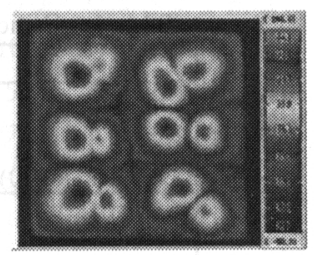

(d) $R a_{l}=2.08 \times 10^{4}$ $q=754.3\left[\mathrm{~W} / \mathrm{m}^{2}\right]$

Fig. 7 Visualized Thermal Patterns (Type A, $v=100$ [cst], $\delta=10[\mathrm{~mm}]$ )

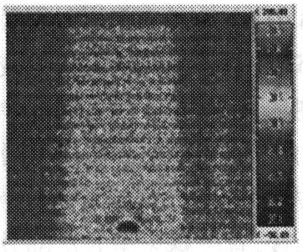

(a) $R a_{l}=1.05 \times 10^{3}$ $q=6.6\left[\mathrm{~W} / \mathrm{m}^{2}\right]$

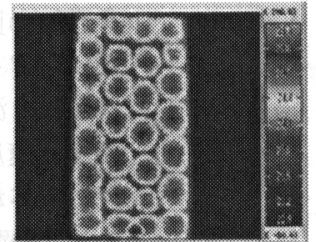

$$
\begin{gathered}
\text { (b) } R a_{l}=5.98 \times 10^{3} \\
q=69.4\left[\mathrm{~W} / \mathrm{m}^{2}\right]
\end{gathered}
$$

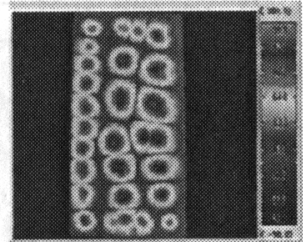

(c) $R a_{l}=7.17 \times 10^{4}$ $q=768.5\left[\mathrm{~W} / \mathrm{m}^{2}\right]$

Fig. 8 Visualized Thermal Patterns (Type B, $v=100[\mathrm{cst}], \delta=10[\mathrm{~mm}]$ ) 


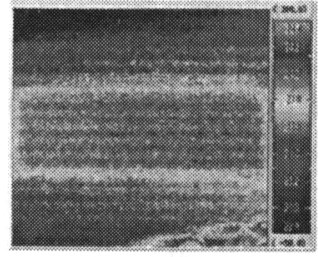

(a) $R a_{l}=9.36 \times 10^{2}$ $q=6.24\left[\mathrm{~W} / \mathrm{m}^{2}\right]$

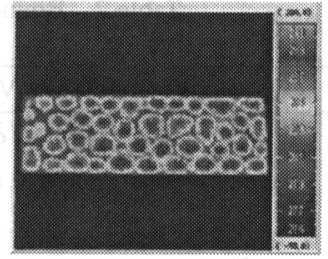

(b) $R a_{l}=6.98 \times 10^{3}$

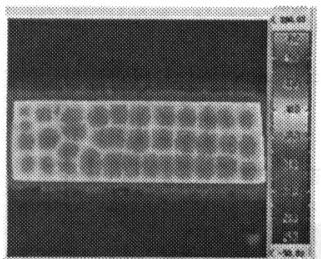

(c) $R a_{l}=3.02 \times 10^{4}$

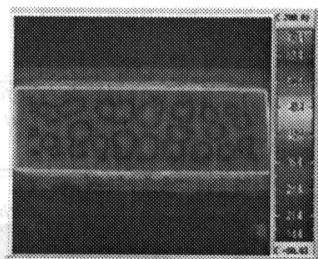

(d) $R a_{l}=8.98 \times 10^{4}$ $q=800.1\left[\mathrm{~W} / \mathrm{m}^{2}\right]$

Fig. 9 Visualized Thermal Patterns (Type C, $v=100$ [cst], $\delta=10[\mathrm{~mm}]$ )

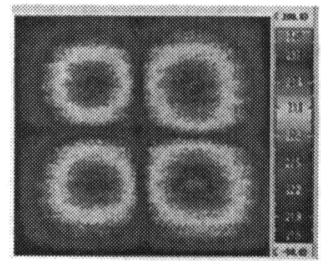

(a)Type A

$R a_{l}=3.43 \times 10^{4}$ $q=140.6\left[\mathrm{~W} / \mathrm{m}^{2}\right]$

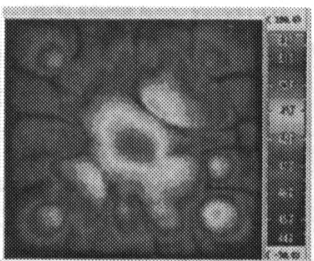

(b)Type A

$R a_{l}=1.93 \times 10^{5}$ $q=723.8\left[\mathrm{~W} / \mathrm{m}^{2}\right]$

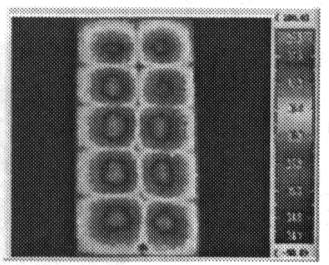

(c)Type B

$R a_{l}=4.64 \times 10^{4}$ $q=144.2\left[\mathrm{~W} / \mathrm{m}^{2}\right]$

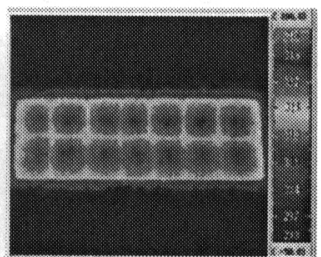

(d)Type C $R a_{l}=3.29 \times 10^{4}$ $q=89.7\left[\mathrm{~W} / \mathrm{m}^{2}\right]$

Fig. 10 Visualized Thermal Patterns ( $v=100[\mathrm{cst}], \delta=15[\mathrm{~mm}])$

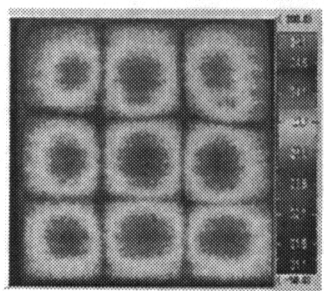

(a) $v=50[\mathrm{cst}]$ $R a_{l}=2.49 \times 10^{3}$

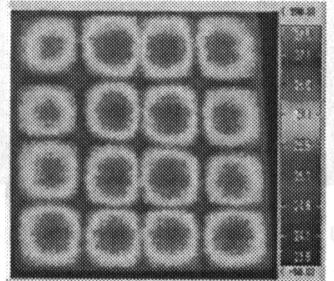

(b) $v=100[\mathrm{cst}]$

$R a_{l}=1.31 \times 10^{4}$

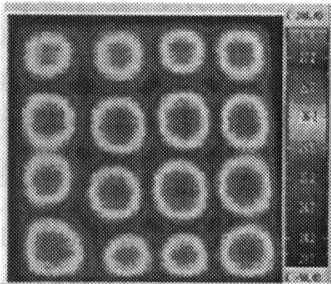

(c) $v=300[\mathrm{cst}]$

$R a_{l}=3.23 \times 10^{3}$

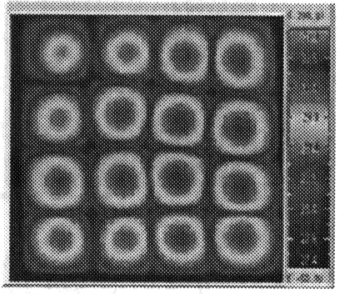

(d) $v=500[\mathrm{cst}]$ $R a_{l}=2.85 \times 10^{3}$

Fig. 11 Visualized Thermal Patterns (Type A, $\delta=10[\mathrm{~mm}], q \doteqdot 170\left[\mathrm{~W} / \mathrm{m}^{2}\right]$ )

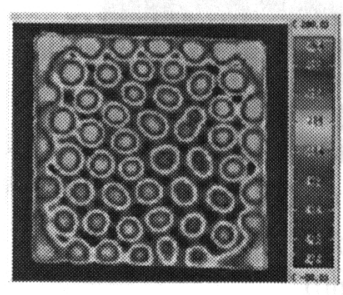

(a)Thermal Pattern

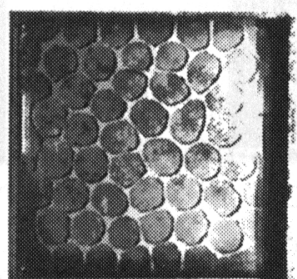

(b)Flow Pattern

Fig. 12 Visualized Patterns

(Type A, $v=300[\mathrm{cst}], \delta=5[\mathrm{~mm}], R a_{l}=1.25 \times 10^{3}$ ) た熱流動現象とアルミパウダーで可視化した熱流動 現象は良好に対応しているものと推察できる.すなわ ち, 赤外線計測は, 気液界面の熱流動現象を可視化す る上でも有効な手段と言える.

3.3 数値解析結果本研究では, 前述の赤外線計 測から得られた可視化結果について, その有効性をさ

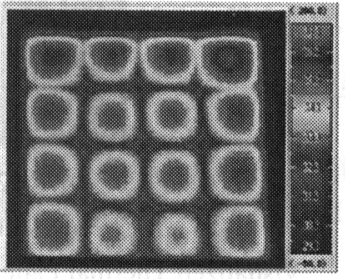

(a)Thermal Pattern

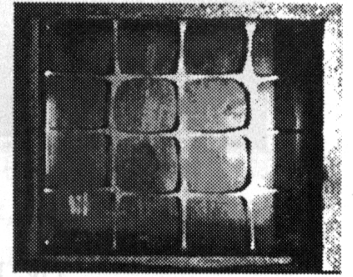

(b)Flow Pattern
Fig. 13 Visualized Patterns

(Type A, $v=300$ [cst], $\delta=10[\mathrm{~mm}], R a_{l}=3.49 \times 10^{4}$ ) らに検証するために数值解析の面からも比較・考察し た. 解析体系は, 図 14 に示すように矩形容器液層内の 熱流動現象を想定している.この際, 運動量式中の浮力 項にはブジネスク近似を適用し, 流体の物性值は可視 化実験により得られた加熱面温度と周囲流体温度との 膜温度 $T_{f}=\left(T_{w}+T_{g}\right) / 2$ で評価した. なお, 計算対象の 


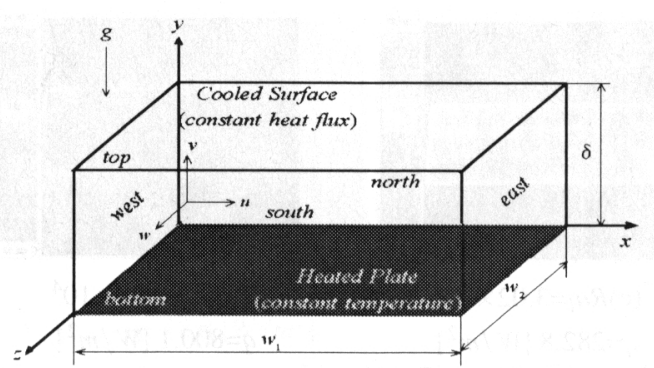

Fig. 14 Analytical Co-ordinate System

Table 2 Boundary Conditions

\begin{tabular}{ccc}
\hline Surface & For Velocity & For Temperature \\
\hline Cooled Surface & $(\partial u, w / \partial y), v=0$ & $q=$ const $(<0)$ \\
Heated Plate & $u, v, w=0$ & $T=T_{w}$ \\
West & $u, v, w=0$ & $\left.\frac{\partial T}{\partial n}\right|_{\text {west }}=0$ \\
East & $u, v, w=0$ & $\left.\frac{\partial T}{\partial n}\right|_{\text {east }}=0$ \\
North & $u, v, w=0$ & $\left.\frac{\partial T}{\partial n}\right|_{\text {north }}=0$ \\
South & $u, v, w=0$ & $\left.\frac{\partial T}{\partial n}\right|_{\text {south }}=0$ \\
\hline
\end{tabular}

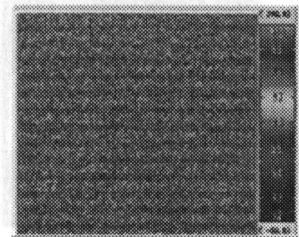

(a) $\bar{T}_{s}=10.01\left[{ }^{\circ} \mathrm{C}\right]$

$q=2.67\left[\mathrm{~W} / \mathrm{m}^{2}\right]$

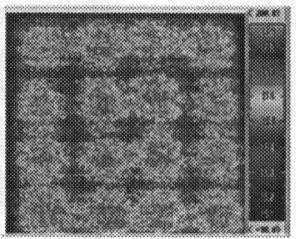

(b) $\bar{T}_{s}=17.58\left[{ }^{\circ} \mathrm{C}\right]$

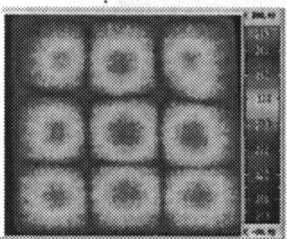

(c) $\bar{T}_{s}=23.49\left[{ }^{\circ} \mathrm{C}\right]$ $q=169.54\left[\mathrm{~W} / \mathrm{m}^{2}\right]$

Fig. 15 Visualized Thermal Patterns (Type A, $v=50[\mathrm{cst}], \delta=10[\mathrm{~mm}]$ )

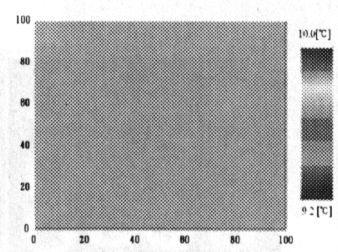

(a) $\bar{T}_{s}=9.98\left[{ }^{\circ} \mathrm{C}\right]$ $q=2.67\left[\mathrm{~W} / \mathrm{m}^{2}\right]$

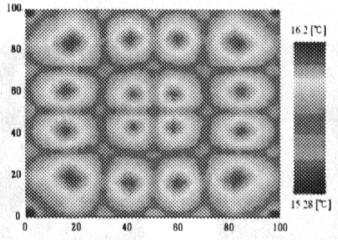

(b) $\bar{T}_{s}=17.39\left[{ }^{\circ} \mathrm{C}\right]$ $q=66.44\left[\mathrm{~W} / \mathrm{m}^{2}\right]$

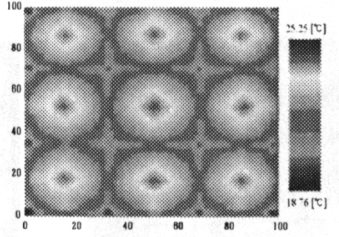

(c) $\bar{T}_{s}=22.34\left[{ }^{\circ} \mathrm{C}\right]$ $q=169.54\left[\mathrm{~W} / \mathrm{m}^{2}\right]$

Fig. 16 Analyzed Isotherms of Surface Temperatures (Type A, $v=50$ [cst], $\delta=10[\mathrm{~mm}]$ )

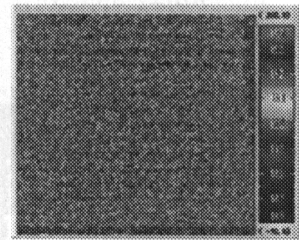

(a) $\bar{T}_{s}=15.27\left[{ }^{\circ} \mathrm{C}\right]$

$q=2.14\left[\mathrm{~W} / \mathrm{m}^{2}\right]$

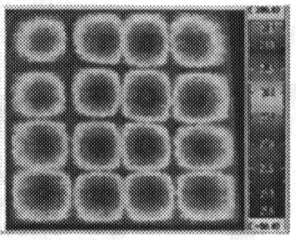

(b) $\bar{T}_{s}=28.02\left[{ }^{\circ} \mathrm{C}\right]$ $q=199.6\left[\mathrm{~W} / \mathrm{m}^{2}\right]$

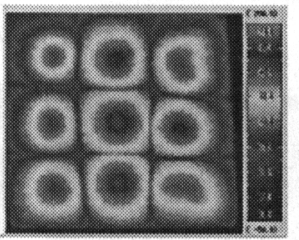

(c) $\bar{T}_{s}=41.06\left[{ }^{\circ} \mathrm{C}\right]$ $q=456.4\left[\mathrm{~W} / \mathrm{m}^{2}\right]$

Fig. 17 Visualized Thermal Patterns (Type A, $v=100$ [cst], $\delta=10[\mathrm{~mm}]$ )

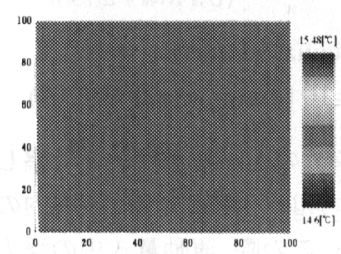

(a) $\bar{T}_{s}=15.09\left[{ }^{\circ} \mathrm{C}\right]$ $q=2.14\left[\mathrm{~W} / \mathrm{m}^{2}\right]$

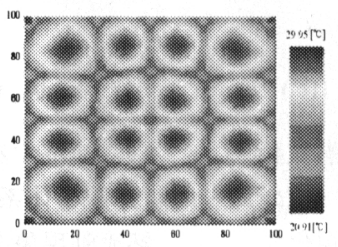

(b) $\bar{T}_{s}=27.41\left[{ }^{\circ} \mathrm{C}\right]$ $q=199.6\left[\mathrm{~W} / \mathrm{m}^{2}\right]$

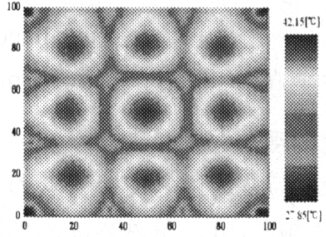

(c) $\bar{T}_{s}=40.62\left[{ }^{\circ} \mathrm{C}\right]$ $q=456.4\left[\mathrm{~W} / \mathrm{m}^{2}\right]$

Fig. 18 Analyzed Isotherms of Surface Temperatures (Type A, $v=100$ [cst], $\delta=10[\mathrm{~mm}]$ ) 
寸法は, 実験装置と同一である.

ここでは, 有次元のままコントロールボリューム法 を用いた輸送方程式の離散化をハイブリッド法で行 い, 3 次元定常数值解析を行った. 流れ場の計算には, SIMPLE 法を用いている. 計算では, 実験条件を可能な 限り再現するため, 境界条件を表 2 のように設定した. すなわち, 実験データに基づいて, 加熱面を等温条件で 加熱し, 泠却面をエネルギーバランスに基づいた等熱 流束条件で冷却し, 四方側面部は断熱条件とした.すな わち, 全て実験において得られた值を適応している. 冷 却面については, 自由界面を想定してすべり境界とし た. 次に格子分割であるが, $x, z$ 方向については, 諸寸 法に対して $1[\mathrm{~mm}]$ 毎に等分割している. $y$ 方向につ いては, 液層樑さに対して $0.5[\mathrm{~mm}]$ 毎に等分割してい る.一方, 初期条件は, 計算領域全体に亘って速度 $u, v$, $w=0$, 流体温度 $T=T_{w}$ とした.

図 15, 図 16 は実験装置 Type A における $v=50$ [cst], $\delta=10[\mathrm{~mm}]$, 図 17 と図 18 は実験装置 Type A における $v=100$ [cst], $\delta=10$ [mm] の気液界面温度場に関する実 験結果と数值解析結果をそれぞれ比較したものである. これらの図から, 実験と数值解析的で得られたベナー ルセルの分布状況が良好に対応していることが分かる. 従って, 本数值解析は, 赤外線による気液界面の定量的 な温度計測を裏付ける上で有効な手段となり得る.

3.4 気夜界面の温度計測結果図 19 は, 気液界 面におけるエネルギーバランスの模式図を示したもの である. 周囲を十分に断熱された有限矩形容器内の気 液界面では, 次式のようなエネルギーバランスが成立 する.

$$
q=q_{c o n v}+q_{r a d}
$$

ここで, $q$ は界面流入熱流束, $q_{\text {conv }}$ は対流熱流束, $q_{r a d}$ はふく射熱流束である.

ベナールセル対流の発生以前は, 流体層内が熱伝導 支配であると考えられるため, 伝熱面温度一定とした 界面流入熱流束は次式で表される。

$$
q=\lambda_{l} \frac{\left(T_{w}-\bar{T}_{s}\right)}{\delta}
$$

一方, ベナールセル対流が発生した後は, 気液界面の温 度場が不均一となるので, 本研究では伝熱面熱流束一 定として次式で示すような印加ジュール加熱量 $q$ と置 き換えて考える.

$$
q=\frac{V I}{A_{0}}-q_{l o s s}
$$

但し, $V$ は印加電圧, $I$ は印加電流, $A_{0}$ は濡れ縁面積 $\left(w_{1} \times w_{2}\left[\mathrm{~mm}^{2}\right]\right)$ である. $q_{l o s s}$ は, 前述の熱流束センサで 計測した実験装置底部からの漏洩熱流束である.また，

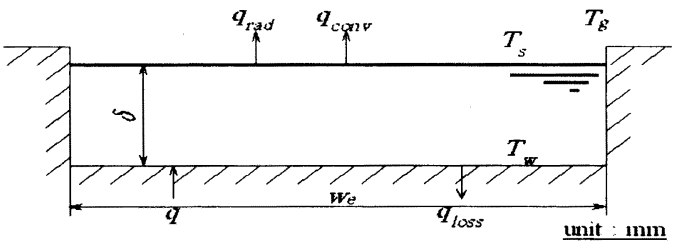

Fig. 19 Energy Balance at Gas-liquid Interface

$q_{\text {rad }}$ は, 界面平均温度 $\bar{T}_{s}$ と周囲流体温度 (気温) $T_{g}$ を 用いて次式により求められる.

$$
q_{\text {rad }}=\varepsilon \sigma\left(\bar{T}_{s}^{4}-T_{g}^{4}\right)
$$

なお, 気液界面の放射率 $\varepsilon$ は, 次式 ${ }^{(9)}$ で求めることがで きる.

$$
\begin{gathered}
a_{s}=\left(\frac{\bar{T}_{r}}{\bar{T}_{s}}\right)^{4.3069} \\
\varepsilon=\frac{a_{s}-\left(T_{g} / \bar{T}_{s}\right)^{4.3069}}{1-\left(T_{g} / \bar{T}_{s}\right)^{4.3069}}
\end{gathered}
$$

ここで, $a_{s}$ は射度係数であり, $\bar{T}_{s}$ と $\bar{T}_{r}$ はそれぞれ濡れ 縁面積当たりの平均界面温度と平均見掛け温度である. 上式より, 本研究で使用した温度範囲内おけるシリコ ンオイルの放射率は, 平均で 0.98 となった. 従って, 赤 外線サーモグラフィーは, 流体層表面の温度をほぼ正 確に測定しているとも考えられる.これらから,気液界 面における平均対流熱伝達率 $h$ 及び平均ヌセルト数 $N u$ は, 次式で求められる.

$$
\begin{gathered}
h=\frac{q_{\text {conv }}}{\bar{T}_{s}-T_{g}}=\frac{q-q_{\mathrm{rad}}}{\bar{T}_{s}-T_{g}} \\
N u=\frac{h w_{e}}{\lambda_{g}}
\end{gathered}
$$

式 ( 8)における $\lambda_{g}$ は, 空気の熱伝導率を表す.また, 空 気側修正レイリー数 $R a_{g}^{*}$ は, 次式で求められる.

$$
R a_{g}^{*}=\operatorname{Pr}_{g} \frac{g \beta_{g} q_{c o n v} w_{e}^{4}}{\lambda_{g} v_{g}^{2}}
$$

式 (9)における $\beta_{g}$ は空気の体積膨張係数, $v_{g}$ は空気の 動粘度である. 気相の物性値は, 平均界面温度と周囲流 体温度との膜温度 $\left[T_{f}=\left(\bar{T}_{s}+T_{g}\right) / 2\right]$ で評価した.ここ で, (8), (9) 式における $w_{e}$ は, 他の容器アスペクト比を 考慮して, 等価直径 $\left[w_{e}=4 w_{1} w_{2} / 2\left(w_{1}+w_{2}\right)\right]$ とした.

これらを踏まえて, 図 20 は実験装置 Type A, Type B, Type C における $v=50,100$ [cst] について, 流体層深さ 毎に気液界面の平均ヌセルト数を空気側修正レイリー 数に対して示したものである. 参考として併記した線 群は, 次式で示される熱流束一定条件下の鉛直固体加 熱平板における層流自然対流 ${ }^{(10),(11)}$, 及び熱流束一定条 件下の水平加熱平板における自然対流 ${ }^{(12)}$ の平均ヌセル ト数である. 


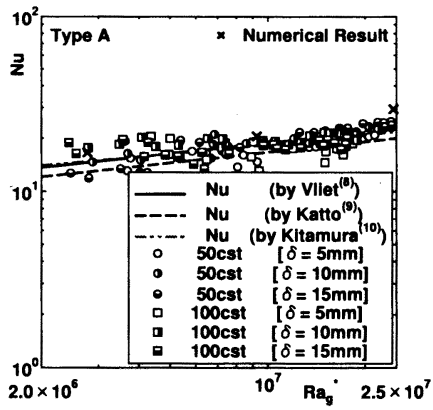

(a)Type A

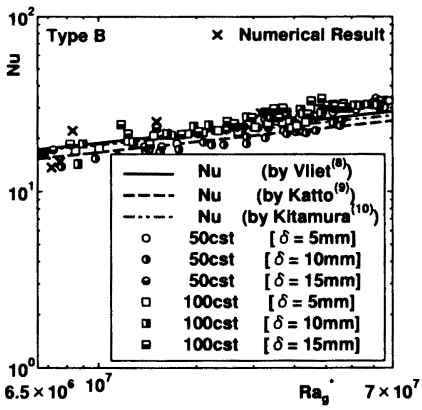

(b)Type B

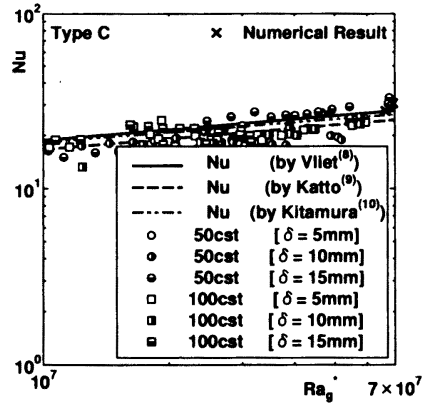

(c)Type C

Fig. 20 Measured Average Nusselt Number

Vliet .,et.al ${ }^{(10)}$ :実線

$$
N u=\frac{5}{4}\left[0.60 R a_{g}^{* 0.2}\right]
$$

甲藤 ${ }^{(11)}$ :一点鎖線

$$
N u=\frac{5}{4}\left[0.53 R a_{g}^{* 0.2}\right]
$$

北村 ${ }^{(12)}:$ 二点鎖線

範囲 $1.6 \times 10^{3}<R a_{g}^{*}<1.6 \times 10^{7}$

$$
N u=1.25 R a_{g}^{* 0.167}
$$

範囲 $1.6 \times 10^{7}<R a_{g}^{*}<8 \times 10^{8}$

$$
N u=0.04 R a_{g}^{* 0.33}+9.7
$$

(10), (11) 式の適用は, 水平面周辺が開いた上向き加 熱の場合, 層流については鉛直面の式を適応してよい とされている伝熱工学資料第 4 版 ${ }^{(13)} に$ 依る. また, 点 群 (計測値) は, 液層内が熱伝導支配下, ベナールセル 対流発生時, 及び乱流状態までの結果を示している.

図 20 から, 液相内でベナールセルが発生した後も, 気液界面における平均熱伝達率と一連の伝熱相関式は, 流体層内の対流状態に依存することなく, 良好に対応 していることが分かる.さらに図 20 中の $\times$ 印は, 平均 界面温度に関する数值解析結果から熱伝達率を算出し たものであり, 実測值や伝熱相関式とも良好に対応し ていることが分かる.このことから, 赤外線による気液 界面の定量的な温度計測を実験と数值解析の両面から も裏付けることができた.

\section{結言}

本研究は, 気液界面の可視化計測や気液界面におけ る温度計測を例に取り上げて, 自然対流の赤外線計測 の有効性を検証したものである. 非接触な赤外線計測 は, 気液界面における温度場の可視化や定量的な温度 計測を実施する上で有効な手法であることを確認する ことができた. 従って, 赤外線計測は, 様々な実用上の 温度・伝熱計測にも対応できるものと考えられる. 赤
外線サーモグラフィーによるリモートセンシング計測 では, 画素毎の二次元的な温度計測が可能なため, 複雑 な形状を有する伝熱面の性能をリアルタイムかつ広範 囲に評価する上で極めて都合が良いと言える.

\section{文献}

(1) T. Inagaki and Y. Okamoto, Measurement of Turbulent Heat Transfer Coefficients Using Infrared Thermography near Ambient Conditions and Its Quantitative Error Estimation, J.of JSME International,Series B, Vol.42, (1998),275.

(2) P. Cerisier, S. Rahal, and N. Rivier, Topological correlations in Benard-Marangoni convective structures, PHYSICAL REVIEW E, Vol.54, Number.5, (1996),5086.

（3）浅枝・玉井・安久・高橋, 大水深および大きな Rayleigh 数における熱対流の性質について, 土木学会論文報告 書,323,(1982),121-131.

（4）浅枝・玉井, 大きな Rayleigh 数をもつ熱対流セル内のプ リュームについて, 土木学会論文報告書,336,(1983),6573.

（5）黒川・稲垣・安久・岡本, 赤外単素子センサを用いた機 械的走查型サーモグラフィー装置の最小検知寸法に及 ぼす要因分析, 可視化情報学会誌,19-74,(1999),51.

(6) K. Kurokawa,T. Inagaki,and M. Agu, A Study on Characteristics of Fundamental Performances for Thermograph, J.of JSME International, Series B,43-4,(2000),671.

(7) 黒川・稲垣・笠井・宮本, 機械的走査形サーモグラフィ 装膡の熱画像ひずみ, 機論 C,69-699,(2003),633.

(8) 日本流体力学会編, 流体力学ハンドブック第 2 版, (1998),292.

(9) T. Inagaki and T. Ishii, On the Proposal of Quantitative Temperature Measurement by Using Three-color Technique Combined with Several Infrared Sensors Having Different Detection Wavelength Bands, Infrared Physics \& Technology,Vol.41,(2000),325.

(10) C.G. Vliet and C.K. Liu, An Experimental Study of Turbulent Natural Convection Boundary Layer, J. of Heat Transfer,Vol.91, (1969),517.

(11) 甲藤, 伝熱概論, (1996),88, 養监堂.

（12）北村・木村水平加熱平面上に生じる自然対流の流動及 び熱伝達（高レイリー数域の伝熱・流動特性），機論 B,60-570,(1994),566.

（13）日本機械学会編, 伝熱工学资料 第 4 版, (1986),68. 